\title{
Contamination of contact lens storage cases by Acanthamoeba and bacteria
}

\author{
D F P Larkin, S Kilvington, D L Easty
}

\begin{abstract}
In order to identify possible risk factors for microbial keratitis the storage cases for contact lenses of 102 asymptomatic lens wearers were tested for contamination by bacteria and free-living amoebae. Of this group 43 had significant counts of viable bacteria and only 40 had negligible counts. Seven had contamination by acanthamoebae, of whom six also had significant bacterial counts. These results were categorised according to the type of contact lens worn and the lens disinfection method. The high rates of contamination by apathogenic and pathogenic organisms, in particular Acanthamoeba, and the probable support by contaminating bacteria of Acanthamoeba, are discussed.
\end{abstract}

Contact lenses have become an increasingly popular mode of correction of refractive errors, and it is estimated that there are now 1.5 million lens wearers in the United Kingdom (G Jones, Association of Contact Lens Manufacturers, personal communication, 1989). Sightthreatening corneal infection by bacteria ${ }^{1}$ or Acanthamoeba ${ }^{23}$ is the most important complication of contact lens wear. Microbial contamination of the storage case is the usual source of infecting organisms. ${ }^{4}$ Soft lens wearers are at greater risk of these infections, probably on account of enhanced microbial adherence to the lens material..$^{56} \mathrm{~A}$ previous survey by Donzis $e t$ $a l^{\prime}$ of the cases of 100 asymptomatic lens wearers found that $46 \%$ were contaminated by bacteria and no cases by Acanthamoeba (although "homemade' saline bottles of two patients were).

A study of the efficacy of lens disinfection was undertaken in which contamination of lens storage cases by bacteria and free-living amoebae (FLA) was ascertained. The study group of 102

Department of

Ophthalmology, Bristol

Eye Hospital, Bristol

D F P Larkin

D L Easty

Public Health

Laboratory, Royal

United Hospital, Bath

S Kilvington

Correspondence to: Mr D F P Larkin, Department of Ophthalmology, Bristol Eye

Hospital, Lower Maudlin

Accepted for publication

1 September 1989
The table shows numbers of patients with lens case contamination by bacteria, Acanthamoeba, and other free-living amoebae (FLA) categorised according to type of contact lens worn. For the purpose of statistical analysis a total viable bacterial count (TVBC) of $<10 / \mathrm{ml}$ is considered negligible, and $>10^{\circ} / \mathrm{ml}$ is considered significant. Note: the other FLA were one isolate each of Vahlkamphia and Hartmannella. included wearers of hard and soft lenses who used a variety of disinfection methods. Particular attention was given to Acanthamoeba, because there has been an exponential increase in incidence of reported Acanthamoeba keratitis in recent years. ${ }^{3}$ This increase is primarily due to infection in contact lens wearers, and among lens wearers those that use home-prepared saline are recognised to be at highest risk. ${ }^{38}$

\section{Patients and methods}

\section{PATIENTS}

One hundred and two patients were recruited. They had been wearing daily-wear lenses for at least six months, were cosmetic lens wearers (using lenses only for correction of minor refractive errors), and had no eye disease. All patients were asymptomatic and were recruited from optometry practices at the time of scheduled review visits. Patients were instructed to bring their lens storage cases and disinfecting solutions, but were not informed about the contamination survey. Participating patients' storage cases were exchanged for new cases. The following information was recorded: lens type, lens disinfecting regimen used, and whether saline solutions were home prepared.

\section{LABORATORY METHODS}

Cases were shaken and opened under aseptic conditions. All solution was transferred to a sterile universal container. A sterile cotton-wool swab moistened with sterile unpreserved saline was then rubbed over the internal surface of the case and the tip added to the universal container. The contents of the container were then mixed in a vortex mixer for 10 seconds, and divided for bacterial and amoebal studies.

Bacterial isolation. Solution was diluted 1:10 into a disinfectant neutraliser and left to stand for 10 minutes. The medium used was that of Norton $e t a l^{9}$ modified here by the inclusion of $0.4 \mathrm{~g} / 1$ of beef liver catalase for peroxide and sodium thiosulphate $20 \mathrm{~g} / 1$ for chlorine. 10 $\mu \mathrm{L}$ aliquots of the neutralised sample were cultured on blood agar and on cysteine, lactose, electrolyte-deficient (CLED) plates. After incubation for two days the isolates showing colony morphology typical of Serratia and all non-lactose-fermenting organisms were subcultured and identified by the API $20 \mathrm{E}$ system 
(API Laboratory Products, Basingstoke).

Total viable bacterial counts (TVBC) were made by the pour-plate method using yeast extract agar. ${ }^{10}$ Serial 10 -fold dilutions to $10^{-6}$ were made in 1/4 strength Ringer's solution. Plates were incubated in air at $30^{\circ} \mathrm{C}$ for three days. A total viable count of $>10^{6} / \mathrm{ml}$ was considered significant for the purpose of analysis.

Amoebal isolation. Remaining storage case solution in the universal which had been vortexed was centrifuged at $2000 \mathrm{~g}$ for 10 minutes. The supernatant was aspirated and the pellet resuspended in $100 \mu \mathrm{l}$ of neutraliser. Previous studies have shown that the neutraliser is not inhibitory to Acanthamoeba trophozoites or cysts (data not shown). This was inoculated on non-nutrient agar seeded with Escherichio coli $^{11}$ and incubated at $30^{\circ} \mathrm{C}$. Plates were examined daily by low power microscopy for seven days. Amoebae were characterised to genus level according to cyst and trophozoite morphology. ${ }^{11}$

Pathogenicity of Acanthamoeba isolates was tested on African green monkey kidney (Vero) cell cultures. ${ }^{12}$ Cell monolayers were inoculated with amoebae, incubated at $32^{\circ} \mathrm{C}$, and examined daily for cytopathic effect.

\section{Results}

A total of 102 lens wearers participated in the study, 45 male and 57 female. The age range of the patients was $17-73$ (mean 32 ) years. Of these, $35(34 \cdot 2 \%)$ wore hard or rigid gas-permeable lenses and $67(65 \cdot 7 \%)$ wore soft lenses. Eightytwo patients used chemical disinfectants, 19 used heat methods, and one used home-prepared saline solution without any recognised disinfecting regimen. In addition to the latter patient four prepared their own saline solution for rinsing after disinfection.

Of the total, the storage case solution of 43 (42\%) patients had TVBC/ml of $>10^{6}$ and 40 had $\mathrm{TVBC} / \mathrm{ml}<10$. Nineteen had $\mathrm{TVBC} / \mathrm{ml}$ between 10 and $10^{6}$. The culture results for the two lens types are shown in Table I. The association between hard lens wear and significant bacterial contamination was statistically significant $\left(\chi^{2}=9 \cdot 38 ; \mathrm{df}=1 ; p<0.05\right)$.

Culture results according to disinfectant method used are shown in Table II. The association of significant bacterial contamination with chlorhexidine was statistically significant $\left(\chi^{2}=\right.$ $5.3 ; \mathrm{df}=1 ; p<0.05)$. This association was not

TABLE II Contamination associated with different lens disinfection systems

\begin{tabular}{|c|c|c|c|c|c|}
\hline $\begin{array}{l}\text { Disinfecting } \\
\text { method }\end{array}$ & No. & $\begin{array}{l}T V B C \\
<10 / m l\end{array}$ & $\begin{array}{l}T V B C \\
>10^{\circ} / \mathrm{ml}\end{array}$ & $\begin{array}{l}\text { Acanthamoeba } \\
\text { contam. }\end{array}$ & $\begin{array}{l}\text { Other } \\
\text { FLA } \\
\text { contam. }\end{array}$ \\
\hline $\begin{array}{l}\text { Chlorhexidine } \\
\text { Hydrogen }\end{array}$ & 35 & 10 & 20 & - & 1 \\
\hline peroxide & 20 & 9 & 3 & - & 1 \\
\hline Heat. & 19 & 13 & 4 & 3 & - \\
\hline Chlorine based & 9 & 1 & 6 & 2 & - \\
\hline Other chemical & 18 & 7 & 9 & 1 & - \\
\hline None & 1 & - & 1 & 1 & - \\
\hline
\end{tabular}

The table shows numbers of patients with lens case contamination by bacteria, Acanthamoeba, and other free-living amoebae (FLA)

categorised according to contact lens disinfection method.

^Home prepared saline but no recognised disinfectant method used. statistically significant for any other disinfection method.

A mixed growth was cultured from most contaminated lens cases. The majority of bacteria were environmental 'pseudomonads', being non-lactose-fermenting, oxidase-positive, Gram-negative bacilli. One recognised corneal pathogen, Serratia marcescens was isolated from 11 cases. Chlorhexidine was the disinfectant used by 10 of these patients and this association was significant (Fisher's exact test; 2 -sided; $p=$ $0 \cdot 04)$. Serratia liquifaciens was isolated from 10 cases. Other lactose-fermenting organisms isolated include Acinetobacter $s p p$, Klebsiella $s p p$, Enterobacter spp, and Aeromonas spp. Pseudomonas aeruginosa was not isolated from any lens case.

Nine patients $(8 \cdot 8 \%)$ had case contamination by free-living amoebae; seven of these were Acanthamoeba, one Vahlkamphia, and one Hartmannella vermiformis. Of the seven patients with Acanthamoeba contamination six were soft lens wearers, six had significant numbers of contaminating bacteria, and six used commercially manufactured disinfecting solutions as instructed. Acanthamoeba was isolated from the case of one of the five patients who prepared saline solution at home: this was the patient who used no disinfectant. All patients were asymptomatic.

All seven Acanthamoeba isolates were cytopathic to Vero cells, producing complete destruction of the cell monolayer in 2-3 days.

\section{Discussion}

We identified a disturbingly high incidence of storage case contamination by bacteria, in accordance with the report of Donzis et al. ${ }^{7} \mathrm{We}$ found that contamination by Serratea marcescens, a recognised corneal pathogen, ${ }^{13}$ was significantly associated with chlorhexidine disinfection. $S$. marcescens infection due to contamination of chlorhexidine hand washing solution has been reported, ${ }^{14}$ and $\mathrm{R}$ plasmids probably transfer resistance in a resistant strain. ${ }^{15}$ However, we found contamination in the cases of patients using all disinfection methods and solutions. Similar bacteria contaminated hard and soft lens cases. The lower rate of bacterial contamination in soft lens cases reflects the use of hydrogen peroxide or heat disinfection by 38 patients in this group, these methods being more effective in reducing bacterial contamination (see Table II). ${ }^{13}$

It is even more disturbing that Acanthamoeba contamination of lens storage cases is more prevalent than expected. Numerically significant bacterial contamination has been found to coexist in most instances. This suggests that bacteria may support Acanthamoeba and possibly enhance virulence. Six of the seven patients from whose cases Acanthamoeba was isolated complied with lens hygiene instructions; only one patient prepared 'home-made' saline solutions, a widely recognised risk factor for Acanthamoeba keratitis.

This study indicates that Acanthamoeba contamination of lens storage cases must be far more common than Acanthamoeba keratitis. Keratitis 
probably arises in only a small proportion of those asymptomatic patients with lens case contamination, and the predisposing factors for development of keratitis have yet to be established.

Tap water rinsing of lenses prior to wear is widely advised by contact lens practitioners. A variety of free-living amoebae, including Acanthamoeba, can be isolated from domestic tap water samples (unpublished observations), and tap water might therefore be a source of contact lens case contamination.

It is established that most disinfecting methods are effective against bacteria and Acanthamoeba in the laboratory ${ }^{16}$; home disinfection does not reflect this in the majority of lens wearers. All must be aware of possible contamination by dangerous pathogens, and lens disinfectant manufacturers must develop new compounds that kill Acanthamoeba cysts. We suggest that tap water rinsing of lenses be strongly discouraged. We further suggest that inexpensive disposable lens storage cases be developed for use and disposal after two weeks. This would reduce the contaminant bacterial population and in some cases abolish Acanthamoeba contamination.

We thank Michael Killpartrick and Marcella McParland, optometrists, for kindly allowing us to survey their patients. This survey was supported in part by the British Council for Prevention of Blindness, Alcon Laboratories Ltd, and the South Western Regional Health Authority.
1 Cooper R, Constable IJ. Infective keratitis in soft contact lens wearers. Br f Ophthalmol 1977; 61: 250-4.

2 Anonymous. Acanthamoeba keratitis [Editorial]. Lancet 1988 i: $687-8$.

3 Moore MB, McCulley JP, Newton C, et al. Acanthamoeba keratitis: a growing problem in soft and hard contact lens wearers. Ophthalmology 1987; 94: 1654-61.

4 Mayo MS, Schlitzer RL, Ward MA, Wilson LA, Ahern DG. Association of Pseudomonas and Serratia corneal ulcers with use of contaminated solutions. F Clin Microbiol 1987; 25. $1398-4000$.

5 Duran JA, Refojo MF, Gibson IK, Kenyon KR. Pseudomonas attachment to new hydrogel contact lenses. Arch Ophthalmol 1987; 105: 106-9.

6 Slusher MM, Myrvik QN, Lewis JC, Gristina AG. Extendedwear lenses, biofilm, and bacterial adhesion. Arch Ophthalmol 1987; 105: 110-5.

7 Donzis PB, Mondino BJ, Weissman BA, Bruckner DA. Microbial contamination of contact lens care systems. $A m \mathcal{F}$ Ophthalmol 1987; 104: 325-33.

8 Stehr-Green JK, Bailey TM, Visvesvara GS. The epidemiology of Acanthamoeba keratitis in the United States. Am $\mathcal{F}$ Ophthalmol 1989; 107: 106-9.

9 Norton DA, Davies DJG, Richardson NE, Meakin BJ, Keal A. The antimicrobial efficiencies of contact lens solutions f Pharm Pharmacol 1974; 26: 841-6.

10 Department of Health and Social Security. The bacteriological examination of water supplies. Report no.71. 4th ed. London: HMSO, 1969.

11 Page FC. A new key to freshwater and soil gynamoebae. Ambleside: Freshwater Biological Association, 1988.

12 Cursons RTM, Brown TJ. Use of cell cultures as an indicator of pathogenicity of free-living amoebae. 7 Clin Pathol 1978; 31: 1-11.

13 Lass JH, Haaf J, Foster CS, Belcher C. Visual outcome in eight cases of Serratia marcescens keratitis. Am 7 Ophthalmol 1981; 92: 384-90.

14 Marrie TJ, Costerton JW. Prolonged survival of Serratia marcescens in chlorhexidine. Appl Environ Microbiol 1981; 42: 1093-102.

15 Okuda T, Endo N, Osada Y, Zen-Yoji H. Outbreak of nosocomial urinary tract infection caused by Serratia marcescens. F Clin Microbiol 1984; 20: 691-5.

16 Ludwig IH, Meisler DM, Rutherford I, Bican FE, Langston RHS, Visvesvara GS. Susceptibility of Acanthamoeba to soft contact lens disinfection systems. Invest Ophthalmol Vis Sc $1986 ; 27: 626-8$. 